\title{
Effects of age and gender on upper airway, lower airway and upper lip growth
}

Renata de Cassia Gonçalves ${ }^{(a)}$ Dirceu Barnabé Raveli(a) Ary dos Santos Pinto ${ }^{(a)}$

(a) Department of Orthodontics, Faculdade de Odontologia de Araraquara, UNESP - Univ Estadual Paulista, Araraquara, SP, Brazil.

\section{Corresponding author:}

Renata de Cassia Gonçalves

Department of Orthodontics, Faculdade de

Odontologia de Araraquara, UNESP - Univ

Estadual Paulista

Rua Humaitá, 1680

CEP: 14801-903

Araraquara - São Paulo - Brazil

E-mail: renatacgoncalves@yahoo.com.br

Received for publication on Nov 03, 2010 Accepted for publication on Mar 18, 2011

\begin{abstract}
The aim of the present retrospective study was to evaluate the influence of age and gender on upper and lower airway width and upper lip length. In this study, 390 lateral cephalograms were divided into 13 age groups (ranging from 6 to 18 years) and were analyzed. The intergroup differences were analyzed using a MANOVA (Multivariate Analysis of the Variance), and the intragroup differences were analyzed using an ANOVA (Analysis of the Variance) and Tukey's test. The results of the present study indicated that although the airway width and the upper lip length increased with age, the lower airway width exhibited variable growth between the ages of six and eighteen years. The airway width was significantly greater in females than males, whereas the upper airway width was similar between these two genders. The lip length was significantly shorter in females than males. The lower airway width and upper lip length were significantly different between males and females, whereas the upper airway width was similar for the genders. The upper airway width and upper lip exhibited incremental growth between the ages of six and eighteen years. The upper lip closely followed the growth pattern of the upper airway width; the growth plateaued between the ages of 6 and 9 years, increased from 9 to 16 years and plateaued from 16 to 18 years.
\end{abstract}

Descriptors: Nasopharynx; Oropharynx; Lip.

\section{Introduction}

Normal respiratory activity influences the growth of maxillofacial structures, favoring advantageous growth and development. ${ }^{1}$ A knowledge of craniofacial growth, dentofacial morphology and normal functioning are essential for the diagnosis, planning and stability of orthodontic treatments. ${ }^{2,3}$

The position of an individual's teeth are in equilibrium with the oral soft tissues (lip, tongue and cheek) and are affected by several functions: respiration, deglutition, chewing and speech. ${ }^{4}$ Mouth breathing becomes necessary when there is a nasal obstruction or anatomical or other predisposing factors. A nasal obstruction can result from hypertrophic palatine tonsils, enlarged pharyngeal tonsils (adenoids) or nasal diseases (e.g., allergic rhinitis). A natural anatomical predisposition includes narrow airway passages (the nose, the upper airway width and the lower airway width), and predisposing factors include environmental irritants and in- 
fections, which are amenable to treatment. ${ }^{5}$

Mouth-breathing children develop postural changes, such as a down and backward mandible posture and a down and forward positioning of the tongue. If these postural changes continue for a long period of time, especially during an individual's active growth stages, various degrees of facial disharmony can develop. This facial disharmony can result in long-face syndrome, an increased anterior face height, incompetent lip seals, short upper lips, and small nostrils. These disorders are frequently accompanied by dental changes, such as an anterior open bite, a posterior crossbite, maxillary dental constriction, and protruding upper incisors. ${ }^{6-8} \mathrm{~Pa}-$ tients may also have a disordered dentofacial morphology that has been corrected with orthopedic and orthodontic treatments. ${ }^{3}$

Mouth breathing is a common alteration with important dentofacial complications in children and adults, male or female, and is associated with various types of facial patterns. Several authors have reported an association between mouth breathing and a vertical growth pattern, ${ }^{8,9}$ whereas other authors have reported a lack of a correlation between the growth pattern and an obstruction of the upper and lower pharyngeal airways in mouth-breathing patients. ${ }^{3,10}$ Several studies have identified a gender difference between upper airway width and lower airway width growth. ${ }^{11,12}$ However, other studies have reported no difference between girls and boys. ${ }^{3,13}$ In addition, several studies have reported that pharynx growth is continuous from infancy to adolescence. ${ }^{11}$ Other studies have assessed the importance of lip morphology in tooth positioning and facial profiles. ${ }^{2,4,14-16}$

The aim of the present retrospective study was to evaluate the influence of age and gender on the upper and lower airway width and the upper lip length in a cohort of healthy subjects, who ranged from six to eighteen years of age, using lateral cephalometry.

\section{Methodology}

The lateral cephalograms of 390 untreated patients (195 females and 195 males), who ranged from 6 to 18 years of age, were collected from the Orthodontic Department's files. Patient radiographs from healthy Caucasian patients without a history of respiratory problems that were obtained using the Funk Orbital Device at Ribeirão Preto, SP, were included in the present study. No samples were excluded because of a malocclusion (152 samples were Angle Class I, 214 were Angle Class II and 24 were Angle Class III). The exclusion criteria included poor radiograph images and images that included evidence of swallowing during the radiograph exposure. The present study was approved by the University Research Ethics Committee.

The patients were divided into thirteen age groups, each of which covered a one-year age interval. Each group was composed of thirty individuals (15 males and 15 females).

Any patient-identifying information was removed from the lateral cephalograms, and these cephalograms were traced and digitized using a Numonics Accugrid light box by a single investigator (RCG). The linear measurements of the upper and lower airway width were recorded using a Mitutoyo Digimatic Caliper (Mitutoyo Products, MitutoyoSul Americana Ltda., São Paulo, Brazil) in a similar manner to McNamara's Analysis. The upper lip length was determined using Ricketts Analysis with Dentofacial Planner Plus 2.01 software (Dentofacial Planner Software Inc., Toronto, Canada). The results of these analyses are presented in Figure 1.

\section{Statistical analysis}

All of the statistical analyses were performed using the SPSS software package ("Statistical Package for the Social Sciences” for Windows, version 16.0, SPSS Inc., Chicago, USA). The method error was assessed using the Intraclass Correlation Coefficient (ICC). The mean values of the replicate measurements were used for the statistical analysis.

A MANOVA (Multivariate Analysis of the Variance) of the between-variable effects for the upper airway width, lower airway width and upper lip length, according to gender and age, was performed. The intragroup differences were compared using a one-way ANOVA (Analysis of the Variance) and Tukey's post hoc test. A 95\% significance level was used for all of the statistical tests $(\mathrm{p}<0.05)$. 




Figure 1 - Measurements on the lateral cephalograms. 1) Upper lip length, measured from the stomion superior to the anterior nasal spine. 2) Upper airway width, measured from a point on the posterior outline of the soft palate to the closest point on the posterior pharyngeal wall. 3) Lower airway width, measured from the intersection of the posterior border of the tongue and the inferior border of the mandible to the closest point on the posterior pharyngeal wall.

\section{Results}

All of the results are summarized in Tables 1, 2, 3 and 4 .

A MANOVA test indicated that there were no correlations between the age and gender effects on the variables of interest. There were no upper airway width differences when the genders were compared; however, there were differences in this width when the age groups were compared. An ANOVA test for the upper airway data also indicated that the increase in the width of this airway was correlated with aging (Table 3). Other ANOVA tests indicated that the lower airway width varied by gender but not by age. The females in the present study exhibited larger lower airway dimensions than those of the males (Table 4). Lastly, an ANOVA test indicated that the upper lip length increases by age but does not differ by gender (Table 4).
Table 1 - Sample description.

\begin{tabular}{|c|c|c|c|}
\hline \multicolumn{2}{|c|}{ Groups } & $\mathrm{N}$ & $\%$ \\
\hline \multirow{2}{*}{$\begin{array}{l}\bar{d} \\
\overline{0} \\
\overline{0} \\
0\end{array}$} & Girls & 195 & 50 \\
\hline & Boys & 195 & 50 \\
\hline \multicolumn{2}{|c|}{ Total } & 390 & 100 \\
\hline
\end{tabular}

$\mathrm{N}=$ number of patients; $\%$ = percentage.

Table 2 - MANOVA test of the between-variable effects.

\begin{tabular}{|c|c|c|c|c|}
\hline Source & Dependent Variable & $\mathrm{F}$ & Sig. & $\begin{array}{c}\text { Observed } \\
\text { Power }\end{array}$ \\
\hline \multirow{3}{*}{$\begin{array}{c}\text { Corrected } \\
\text { Model }\end{array}$} & Upper Lip Length & 9.819 & 0.000 & 1.000 \\
\hline & Lower Airway Width & 1.390 & 0.103 & 0.948 \\
\hline & Upper Airway Width & 10.415 & 0.000 & 1.000 \\
\hline \multirow{3}{*}{ Intercept } & Upper Lip Length & 42682.765 & 0.000 & 1.000 \\
\hline & Lower Airway Width & 3761.131 & 0.000 & 1.000 \\
\hline & Upper Airway Width & 4348.006 & 0.000 & 1.000 \\
\hline \multirow{3}{*}{ Age } & Upper Lip Length & 17.002 & 0.000 & 1.000 \\
\hline & Lower Airway Width & 1.976 & 0.025 & 0.918 \\
\hline & Upper Airway Width & 20.811 & 0.000 & 1.000 \\
\hline \multirow{3}{*}{ Gender } & Upper Lip Length & 29.048 & 0.000 & 1.000 \\
\hline & Lower Airway Width & 5.232 & 0.023 & 0.626 \\
\hline & Upper Airway Width & 0.140 & 0.709 & 0.066 \\
\hline \multirow{3}{*}{$\begin{array}{l}\text { Age * } \\
\text { Gender }\end{array}$} & Upper Lip Length & 1.033 & 0.417 & 0.603 \\
\hline & Lower Airway Width & 0.483 & 0.924 & 0.278 \\
\hline & Upper Airway Width & 0.875 & 0.573 & 0.515 \\
\hline
\end{tabular}

\section{Discussion}

There were no significant gender differences in the upper airway widths of the patients who were between 6 and 18 years of age (Table 3, Figure 2). In addition, there was no sexual dimorphism in the 2D lateral cephalometric analyses or the 3D airway measurements of preadolescents. ${ }^{17}$ The increase in the upper airway width reflected differential growth patterns in males and females ranging from 4 to 18 years of age and from 4 to 26 years of age,,$^{13}$ respectively. The lower airway width was significantly wider in females than in males (Table 4, Figures 3a and $3 \mathrm{~b})$. These results are in agreement with previous results gathered by Ceylan and Oktay ${ }^{18}$ that showed a significant difference in the oropharyngeal measurements between genders in subjects who 
Table 3 - Descriptive statistics for the upper airway width.

\begin{tabular}{c|c|c|c}
\hline Age & Mean & $\dagger$ & S.D. \\
\hline 6 & 8.92 & $\mathrm{a}$ & 2.74 \\
\hline 7 & 8.90 & $\mathrm{a}$ & 2.93 \\
\hline 8 & 9.12 & $\mathrm{a}$ & 2.72 \\
\hline 9 & 8.75 & $\mathrm{a}$ & 3.06 \\
\hline 10 & 10.52 & $\mathrm{ab}$ & 3.54 \\
\hline 11 & 10.44 & $\mathrm{ab}$ & 3.81 \\
\hline 12 & 11.41 & $\mathrm{abc}$ & 4.13 \\
\hline 13 & 12.59 & $\mathrm{bcd}$ & 4.15 \\
\hline 14 & 13.96 & $\mathrm{cde}$ & 4.23 \\
\hline 15 & 15.60 & $\mathrm{de}$ & 4.60 \\
\hline 16 & 15.41 & $\mathrm{de}$ & 4.09 \\
\hline 17 & 16.39 & $\mathrm{e}$ & 3.63 \\
\hline 18 & 16.55 & $\mathrm{e}$ & 3.04 \\
\hline
\end{tabular}

† Post hoc test (Tukey).

Table 4 - Descriptive statistics for the lower airway width and upper lip length.

\begin{tabular}{|c|c|c|c|c|c|c|c|c|c|c|}
\hline \multirow{3}{*}{ Age } & \multicolumn{5}{|c|}{ Female } & \multicolumn{5}{|c|}{ Male } \\
\hline & \multicolumn{2}{|c|}{ Lower airway width } & \multicolumn{3}{|c|}{ Upper lip length } & \multicolumn{2}{|c|}{ Lower airway width } & \multicolumn{3}{|c|}{ Upper lip length } \\
\hline & Mean & S.D. & Mean & $\dagger$ & S.D. & Mean & S.D. & Mean & $\dagger$ & S.D. \\
\hline 6 & 18.56 & 4.76 & 23.23 & $a b$ & 1.56 & 16.37 & 3.72 & 23.99 & a & 2.14 \\
\hline 7 & 18.31 & 4.12 & 22.41 & a & 1.93 & 16.00 & 4.15 & 23.57 & a & 2.28 \\
\hline 8 & 17.04 & 4.57 & 22.51 & a & 2.01 & 15.34 & 5.80 & 23.95 & a & 1.61 \\
\hline 9 & 17.70 & 4.32 & 23.01 & $a b$ & 3.18 & 14.66 & 5.00 & 24.64 & a & 1.80 \\
\hline 10 & 19.40 & 4.45 & 23.99 & $a b$ & 3.09 & 18.58 & 5.37 & 25.73 & $a b c$ & 1.98 \\
\hline 11 & 20.14 & 5.73 & 24.69 & $\mathrm{abcd}$ & 2.62 & 18.96 & 4.67 & 24.97 & $a b$ & 1.99 \\
\hline 12 & 19.90 & 6.46 & 25.69 & bcd & 1.06 & 18.06 & 8.74 & 26.26 & abcd & 2.38 \\
\hline 13 & 18.96 & 5.12 & 26.49 & $\mathrm{~cd}$ & 2.91 & 16.38 & 6.05 & 26.57 & abcde & 1.96 \\
\hline 14 & 22.07 & 5.17 & 25.99 & bcd & 2.56 & 20.03 & 5.87 & 27.80 & bcde & 2.91 \\
\hline 15 & 19.32 & 7.99 & 26.75 & $\mathrm{~cd}$ & 1.70 & 18.55 & 4.30 & 27.97 & bcde & 3.54 \\
\hline 16 & 18.32 & 7.49 & 26.73 & $\mathrm{~cd}$ & 1.61 & 16.29 & 5.25 & 28.83 & de & 2.32 \\
\hline 17 & 20.51 & 9.26 & 27.45 & $d$ & 2.93 & 20.44 & 7.84 & 28.45 & cde & 2.96 \\
\hline 18 & 16.89 & 6.04 & 25.85 & bcd & 3.40 & 19.70 & 6.43 & 29.45 & e & 3.12 \\
\hline
\end{tabular}

† Post hoc test (Tukey). A post hoc test of the lower airway space data showed no statistically significant differences.

were 13 to 15 years of age. In contrast, the results of research by Adamidis and Spyropoulos ${ }^{19}$ did not indicate any gender differences in the lower airway width of patients who were an average of 9.3 years of age.

In the present study, the upper airway width increased significantly from six to eighteen years

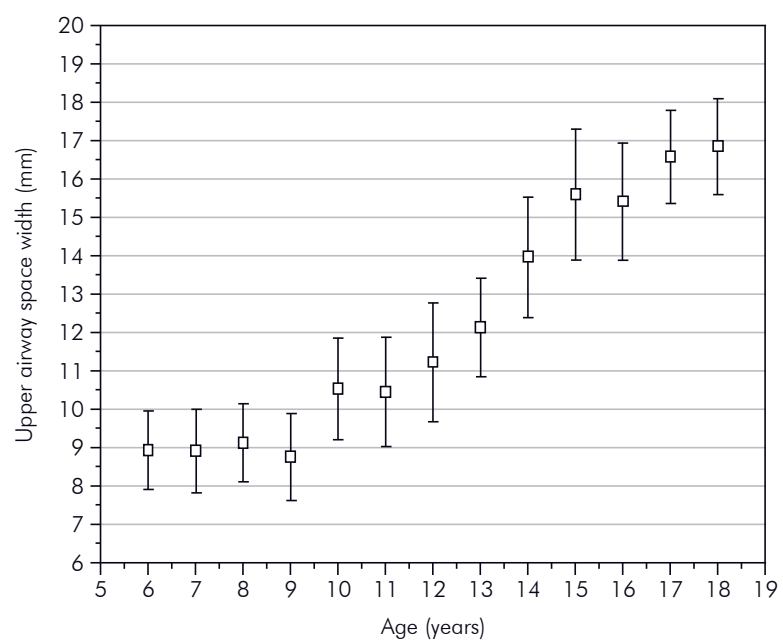

Figure 2 - Growth changes in the upper airway width, from 6 to 18 years of age. The graph shows the means and quartile ranges in millimeters $(95 \% \mathrm{Cl})$. 

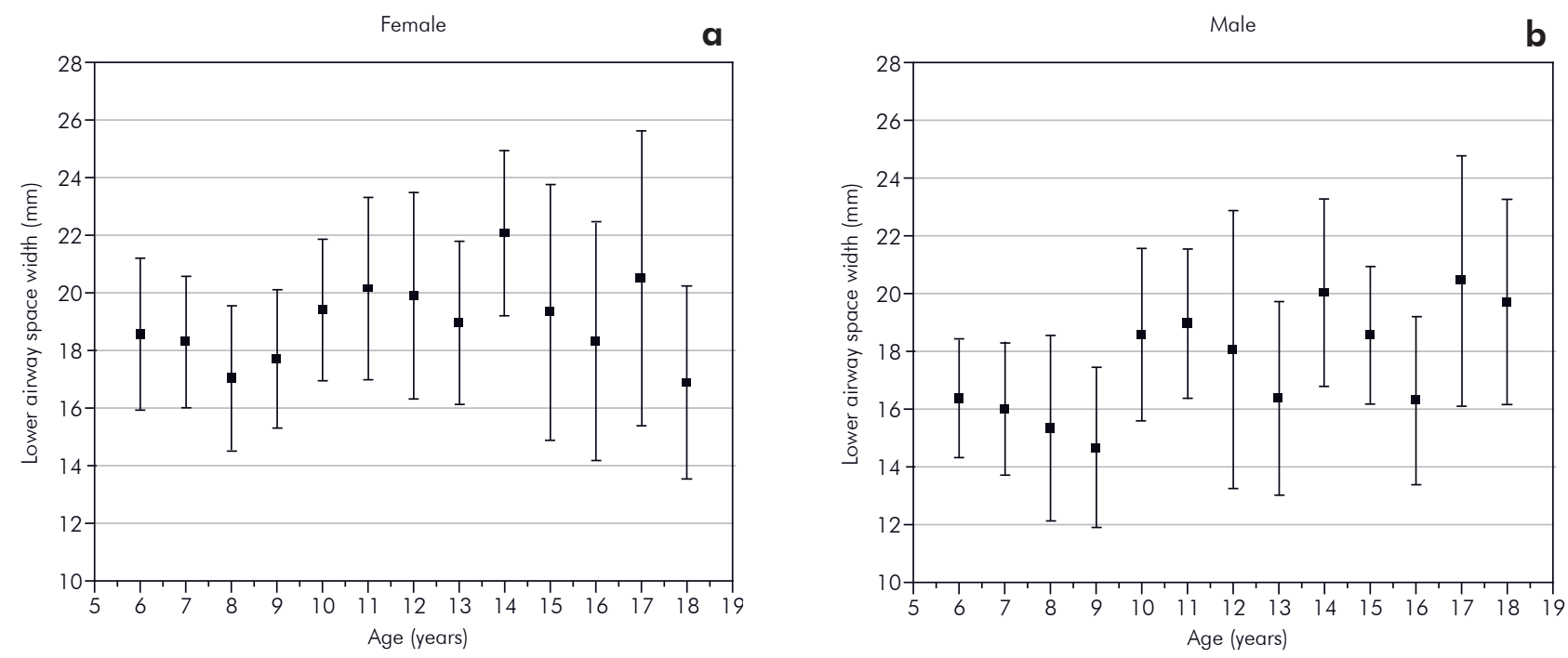

Figure 3 - Growth changes in the lower airway width, from 6 to 18 years of age. The graph shows the means and quartile ranges in millimeters. a. female, b. male $(95 \% \mathrm{Cl})$.

sils and adenoids, that surround the upper airway grow in proportion to the growth of the skeletal structures throughout the first decade of life. The oral soft tissues reach their maximum size between 7 and 10 years of age. ${ }^{20}$ Then, these tissues progressively decrease in size until 60 years of age. ${ }^{21} \mathrm{~A}$ similar growth pattern was identified in this study, especially an increase in the nasopharyngeal dimensions from 9 to 16 years of age.

In the present study, the lower airway width demonstrated variable growth with no statistical differences among any of the age groups (Table 4, Figures $3 \mathrm{a}$ and $3 \mathrm{~b}$ ). This variability may be explained by one or more of the following factors:

- the continued growth of the pharynx,

- lymphoid tissue regression,

- the presence or absence of the enlarged palatine tonsils, and

- the positions of the tongue in relation to the mandible and maxilla. ${ }^{20}$

A wider lower airway width may be due to a malpositioning of the tongue or to enlarged palatine tonsils causing a mandibular prognatism..$^{1,12}$

Under normal conditions, the forward translation of the mandible likely contributes to the forward positioning of the hyoid bone, whereas the growth of the cervical vertebrae contributes to hyoid bone descent. ${ }^{20,22}$ When there is an obstructive condition, the anteroposterior dimension of the lower airway width needs to be maintained. Therefore, the mandible is moved down and backward in relation to the other craniofacial structures, whereas the tongue and hyoid are not. Thus, the hyoid-associated structures (the pharyngeal, cervical and dorsal muscular structures) are guided to a forward position to avoid compromising the size of the airway ${ }^{5}$. When these postural adaptations of the tongue, hyoid and cervical vertebrae are not sufficient to maintain the size of the airway, other compensatory mechanisms develop. For example, the lips part, ${ }^{8,23}$ the mandible moves downward to increase the airway space $^{8}$ and the tongue assumes a lower ${ }^{24}$ or more forward ${ }^{8}$ position within the oral cavity. However, this altered reflex behavior of the lower airway width is not identical in all subjects. Consequently, different oropharyngeal widths have been observed among individuals. ${ }^{5}$

In the present study, there were no differences in the upper lip length by gender; however, there was an increase in the upper lip length by age (Table 4, Figures $4 \mathrm{a}$ and $4 \mathrm{~b})$. These results are in support of a careful analysis of the results of previous studies that suggested that gender differences of the upper lip length and age differences should be considered. ${ }^{14,15,16,25,26}$ Other authors ${ }^{4}$ have reported similar 

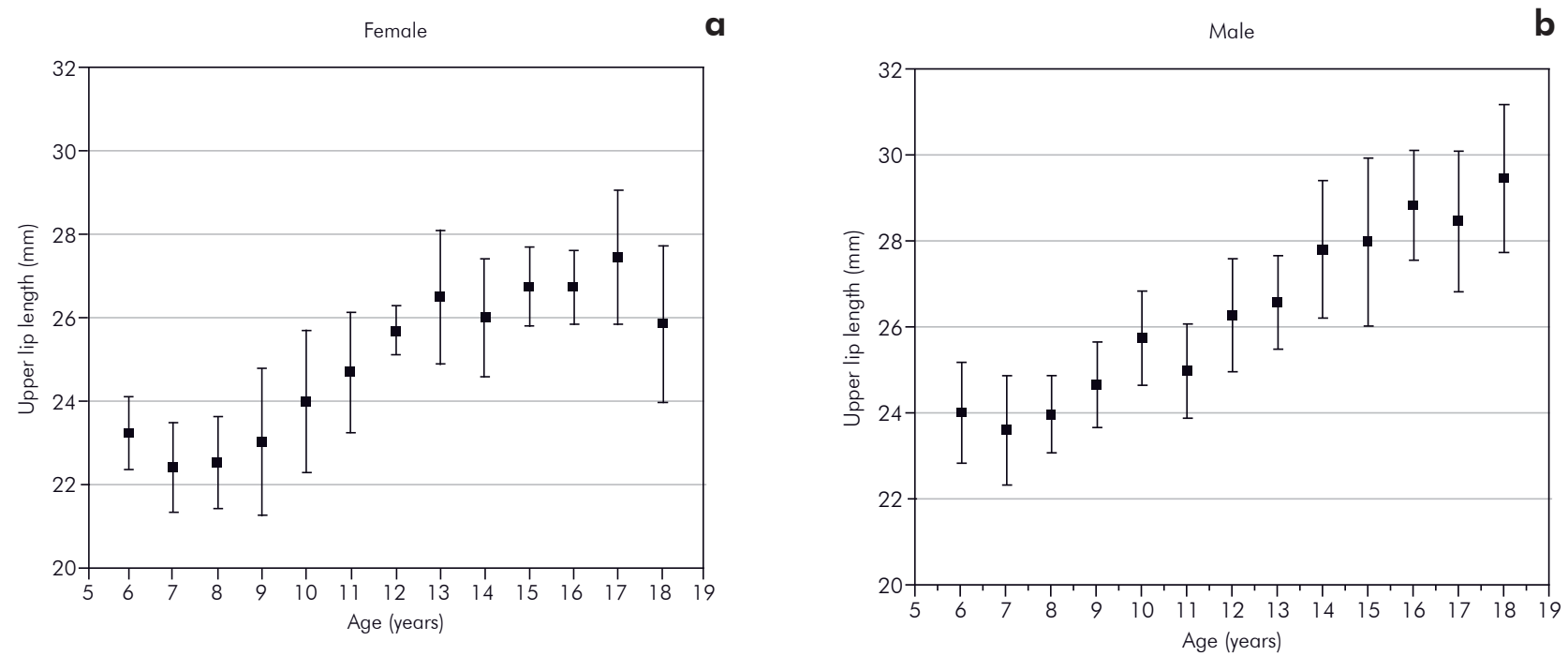

Figure 4 - Growth changes in the upper lip length, from 6 to 18 years of age. The graph shows the means and quartile ranges in millimeters. a. female, b. male $(95 \% \mathrm{Cl})$.

findings of a vertical growth of the upper lip, which reaches a plateau by 15 years of age. The results of the current study indicated vertical increases of the upper lip of 23.3 to $26.6 \mathrm{~mm},{ }^{4} 20.5$ to $25.0 \mathrm{~mm}^{15}$ and 19.1 to $22.5 \mathrm{~mm} .{ }^{27} \mathrm{In}$ addition to its obvious importance to the facial profile, lip morphology is of considerable significance in tooth positioning., ${ }^{4,27}$ When the lips cannot perform their function properly, this leads to a gradual protrusion of the anterior teeth and to the establishment of a Class II, division 1 malocclusion ${ }^{28}$. When the tongue is forward, it causes habitual anterior mandibular posturing and, consequently, a prognatism..$^{1,12}$

The data from the present study demonstrated that the upper lip closely follows the growth pattern of the upper airway width. There is a growth plateau from 6 to 9 years, a progressive increase from 9 to 16 years, and another plateau from 16 to 18 years of age (Table 3, Figures 2, 4a and 4b). The formfunction interaction may explain the causal association between nasal obstruction and facial growth in children. ${ }^{10}$ In contrast, no correlations have been

\section{References}

1. Takemoto Y, Saitoh I, Iwasaki T, Inada E, Yamada C, Iwase $\mathrm{Y}$, et al. Pharyngeal airway in children with prognathism and normal occlusion. Angle Orthod. 2011 Jan;81(1):77-82. observed between the shape and function of the upper lip for nasal or mouth breathing, according to previous authors. ${ }^{10,29}$ Small changes in the upper lip length and the linear relationship prediction equations indicate that patients with a short upper lip at 7 years are likely to have a short upper lip at age $18 .{ }^{27}$

\section{Conclusions}

1. The upper airway width is similar between genders but increases with age.

2. The lower airway width is significantly wider in females than in males. This parameter exhibits variable growth.

3. The upper lip length is similar between males and females but increases with age.

4. The growth of the upper lip closely follows the growth pattern of the upper airway width. It exhibits a growth plateau from 6 to 9 years, a linear increase from 9 to 16 years and another growth plateau from 16 to 18 years of age.

2. Bishara SE, Jakobsen JR, Hession TJ, Treder JE. Soft tissue profile changes from 5 to 45 years of age. Am J Orthod Dentofacial Orthop. 1998 Dec;114(6):698-706. 
3. Shanker S, Fields HW, Beck FM, Vig PS, Vig KWL. A longitudinal assessment of upper respiratory funcion and dentofacial morphology in 8- to 12-year-old children. Semin Orthod. 2004 Mar;10(1):45-53.

4. Vig PS, Cohen AM. Vertical growth of the lips: a serial cephalometric study. Am J Orthod 1979 Apr;75(4):405-15.

5. Tourne LP. Growth of the pharynx and its physiologic implications. Am J Orthod Dentofacial Orthop. 1991 Feb;99(2):12939.

6. Linder-Aronson S. Respiratory function in relation to facial morphology and the dentition. Br J Orthod. 1979 Apr;6(2):5971.

7. Preston CB, Tobias PV, Salem OH. Skeletal age and growth of the nasopharynx in the sagittal plane: A cephalometric study. Semin Orthod. 2004 Mar;10(1):16-38.

8. Subtelny JD. Oral respiration: facial maldevelopment and corrective dentofacial orthopedics. Angle Orthod. 1980 Jul;50(3):147-64.

9. de Freitas MR, Alcazar NM, Janson G, de Freitas KM, Henriques JF. Upper and lower pharyngeal airways in subjects with Class I and Class II malocclusions and different growth patterns. Am J Orthod Dentofacial Orthop. 2006 Dec;130(6):742-5.

10. Ambrosio AR, Trevilatto PC, Sakima T, Ignacio SA, Shimizu RH. Correlation between morphology and function of the upper lip: a longitudinal evaluation. Eur J Orthod. 2009 Jun;31(3):306-13.

11. Ronen O, Malhotra A, Pillar G. Influence of gender and age on upper-airway length during development. Pediatrics. 2007 Oct;120(4):e1028-34.

12. Battagel JM, Johal A, L'Estrange PR, Croft CB, Kotecha B. Changes in airway and hyoid position in response to mandibular protrusion in subjects with obstructive sleep apnoea (OSA). Eur J Orthod. 1999 Aug;21(4):363-76.

13. Martin O, Muelas L, Vinas MJ. Nasopharyngeal cephalometric study of ideal occlusions. Am J Orthod Dentofacial Orthop. 2006 Oct;130(4):436 e1-9.

14. Burstone CJ. Lip posture and its significance in treatment planning. Am J Orthod. 1967 Apr;53(4):262-84.

15. Park YC, Burstone CJ. Soft-tissue profile--fallacies of hardtissue standards in treatment planning. Am J Orthod Dentofacial Orthop. 1986 Jul;90(1):52-62.
16. Yuen SW, Hiranaka DK. A photographic study of the facial profiles of southern Chinese adolescents. Quintecensse Int. 1989 Sep;20(9):665-76.

17. Kim YJ, Hong JS, Hwang YI, Park YH. Three-dimensional analysis of pharyngeal airway in preadolescent children with different anteroposterior skeletal patterns. Am J Orthod Dentofac. 2010 Mar;137(3):306.e1-.e11.

18. Ceylan I, Oktay H. A study on the pharyngeal size in different skeletal patterns. Am J Orthod Dentofacial Orthop. 1995 Jul;108(1):69-75.

19. Adamidis IP, Spyropoulos MN. The effects of lymphadenoid hypertrophy on the position of the tongue, the mandible and the hyoid bone. Eur J Orthod. 1983 Nov;5(4):287-94.

20. Taylor M, Hans MG, Strohl KP, Nelson S, Broadbent BH. Soft tissue growth of the oropharynx. Angle Orthod. 1996;66(5):393-400.

21. Vogler RC, Ii FJ,;Pilgram TK. Age-specific size of the normal adenoid pad on magnetic resonance imaging. Clin Otolaryngol Allied Sci. 2000 Oct;25(5):392-5.

22. Moss ML, Salentijn L. The primary role of functional matrices in facial growth. Am J Orthod. 1969 Jun;55(6):566-77.

23. Subtelny J. The Significance of Adenoid tissue in Orthodontia. Angle Orthod. 1954;24(2):59-69.

24. Linder-Aronson S. Effects of adenoidectomy on dentition and nasopharynx. Trans Eur Orthod Soc. 1972:177-86.

25. Arnett GW, Jelic JS, Kim J, Cummings DR, Beress A, Worley CM, Jr., et al. Soft tissue cephalometric analysis: diagnosis and treatment planning of dentofacial deformity. Am J Orthod Dentofacial Orthop. 1999 Sep;116(3):239-53.

26. Fernandez-Riveiro P, Suarez-Quintanilla D, Smyth-Chamosa E, Suarez-Cunqueiro M. Linear photogrammetric analysis of the soft tissue facial profile. Am J Orthod Dentofacial Orthop. 2002 Jul;122(1):59-66.

27. Nanda RS, Meng H, Kapila S, Goorhuis J. Growth changes in the soft tissue facial profile. Angle Orthod. 1990 Fall;60(3):177-90.

28. Ambrosio AR, Trevilatto PC, Martins LP, Santos-Pinto A, Shimizu RH. Electromyographic evaluation of the upper lip according to the breathing mode: a longitudinal study. Braz Oral Res. 2009 Oct-Dec;23(4):415-23.

29. Kluemper GT, Vig PS,;Vig KW. Nasorespiratory characteristics and craniofacial morphology. Eur J Orthod. 1995 Dec;17(6):491-5. 